\title{
The antiviral protein Cyanovirin-N: The current state of its production and applications
}

\author{
Sheng XIONG ${ }^{\text {a, }}$, Jun FAN ${ }^{\text {a }}$, and Kaio KITAZATO ${ }^{b}$ \\ a Biomedical R\&D Center, Guangdong Provincial Key Laboratory of Bioengineering \\ Medicine, National Engineering Research Center of Genetic Medicine, Jinan University. \\ Guangzhou, Guangdong, P. R. China 510632 \\ ${ }^{b}$ Division of Molecular Pharmacology of Infectious Agents, Department of Molecular \\ Microbiology and Immunology, Graduate School of Biomedical Sciences, Nagasaki \\ University. Nagasaki City, 1-14 Bunkyo-machi, Nagasaki, 852-8521, Japan
}

Correspondence:

Dr. S XIONG, Biomedical R\&D Center, Jinan University, Guangzhou, Guangdong, 510632, P. R. China. Phone: +86-20-85220504-311. Fax: +86-20-85220504-309. Email: xiongsheng@jnu.edu.cn.

Prof. K KITAZATO, Division of Molecular Pharmacology of Infectious Agents, Department of Molecular Microbiology and Immunology, Graduate School of Biomedical Sciences, Nagasaki University. Nagasaki City, 1-14 Bunkyo-machi, Nagasaki, 852-8521, Japan. Phone: +81-95-819-2457. Fax: +81-95-819-2898. Email: kkholi@nagasaki-u.ac.jp

Running title: Current state of CVN's production and application 


\begin{abstract}
HIV/AIDS continues to spread worldwide, and most of the HIV-infected people living in developing countries have little or no access to highly active antiretroviral therapy. The development of efficient and low-cost microbicides to prevent sexual transmission of HIV should be given high priority because there is no vaccine available yet. Cyanovirin-N (CVN) is an entry inhibitor of HIV and many other viruses, and it represents a new generation of microbicide that has specific and potent activity, a different mechanism of action and unusual chemicophysical stability. In vitro and in vivo antiviral tests suggested that the anti-HIV effect of CVN is stronger than a well-known gp120-targeted antibody (2G12) and another microbicide candidate, $\mathrm{PRO} 2000 . \mathrm{CVN}$ is a cyanobacteria-derived protein that has special structural features, making the artificial production of this protein very difficult. In order to develop an efficient and relatively low cost approach for large scale production of recombinant CVN to satisfy medical use, this protein has been expressed in many systems by trial-and-error. Here, to summarize the potential, and remaining challenges, for the development of this protein into an HIV prevention agent, the progress in the structural mechanism determination, heterologous production, and pharmacological evaluation of CVN is reviewed.
\end{abstract}

Keywords: Human immunodeficiency virus; microbicide; Cyanovirin-N; gp120 binding; pharmacological evaluation; heterologous production; 


\section{Introduction}

Human immunodeficiency virus (HIV) remains a global health problem of unprecedented dimensions. Globally, there are an estimated 33 million people living with HIV (UNAIDS 2008). The continuing HIV epidemic highlights the urgent need for additional effective methods of prevention. Major efforts have been focused on developing vaccines, but the high genetic variability of HIV makes this approach very difficult, and protection remains elusive (Cohen 2009). While condoms are highly effective at preventing HIV transmission, they are a contraceptive that requires partner consent and consequently are not an available option for many women at risk of HIV infection (Shattock et al. 2004). Thus, new prevention approaches that can be initiated (controlled) by women are desperately needed. One solution is the development of topical microbicides that can be applied vaginally (and possibly rectally) to prevent HIV transmission (Grant et al. 2008). A broad range of compounds, including specific entry inhibitors of viral envelope or cellular receptors, are currently in development as microbicide candidates (Balzarini and Van Damme. 2007). Cyanovirin-N (CVN), an entry inhibitor of HIV that was initially isolated from the cyanobacterium Nostoc ellipsosporum (Boyd et al. 1997), represents a new generation of microbicides due to its specific and potent activity, different mechanism of action and unusual chemicophysical stability. In vivo studies with CVN formulated as a gel have shown promising efficacy as a microbicide candidate. In addition, a recent ex vivo test showed that the antiviral effect of CVN is stronger than that of PRO 2000 (Fischetti et al. 2009; Huskens et al. 2009), a non-specific polyanion microbicide. The greater activity and specificity of CVN may provide a more effective next generation approach to microbicide development. In addition to properly evaluating its pharmacological action, another formidable challenge for the development of CVN is how to produce biologically active recombinant $\mathrm{CVN}(\mathrm{rCVN})$ on a large scale with the relatively low cost necessary to satisfy medical use. In this review, we summarize the general knowledge as well as the potential application of $\mathrm{CVN}$, and then focus on the advances in large-scale production.

\section{Structural characteristics of CVN}

CVN has a unique sequence of 101 amino acid residues (Boyd et al. 1997). Although the two 
halves (residues 1-50 and 51-101) in CVN share a high degree of sequence homology, CVN has an extremely low sequence homology with any other known protein. It has no homology greater than 8 contiguous amino acids or $20 \%$ of the total sequence to any other known protein. In addition, this protein contains four cysteines that form two intramolecular disulfide bonds. Disruption of these disulfide bonds results in the loss of CVN's anti-HIV activity (Bewley et al. 1998; Yang et al. 1999). The disulfide bonds and lack of sequence homology makes the artificial production of this protein very difficult.

At this point in time, the structure of CVN and its mutants have been solved a total of 23 times using crystallography or NMR (Protein Data Bank, http://www.rcsb.org/pdb/home/home.do). The protein displays an internal two-fold pseudosymmetry, and the two repeat sequences do not form separate domains (Bewley et al. 1998). Wild type (WT) CVN is a monomer in solution and exhibits a domain-swapped dimer in the crystal form (Fig. 1A) (Barrientos et al. 2002). The monomer is comprised of two independent carbohydrate binding sites that individually bind to di- and tri-mannoses [Fig. 1B] of the gp120 protein of HIV-1 with an affinity that is stronger than that of the broadly neutralizing anti-HIV-1 antibody $2 \mathrm{G} 12$, another gp120-targeting entry inhibitor (Botos et al. 2002). High-affinity binding through multivalent binding sites on CVN and clustered oligomannosides on gp120 is essential for CVN's antiviral activity. Mutants containing two or more binding sites are functional at low nanomolar concentrations. Monovalent, monomeric mutants of $\mathrm{CVN}$ are inactive in inhibiting viral entry, and bind gp120 with greatly reduced affinity. Constructs containing a single carbohydrate-binding domain that are capable of forming domain swapped dimmers are also functional (Liu et al. 2009). Owing to its special sequence and 3D structure, CVN is insensitive to denaturants, detergents, organic solvents, and extreme temperatures. These features strengthen its potential as a microbicide, as well as providing a simple heat precipitation process to separate it from other host proteins when it is expressed in heterologous bacteria or cells.

\section{Production of CVN in heterologous hosts}

The production of recombinant proteins in a highly purified and well-characterized form has become a major part of the pharmaceutical biotechnologists job (Terpe 2006). As a promising 
microbicide candidate, a $5 \mathrm{mg}$ dose of $\mathrm{CVN}$, which proved to be effective in macaque studies, requires a production capacity of $5000 \mathrm{~kg}$ a year to supply twice weekly doses for just 10 million women (Shattock et al. 2003). This scale of protein production may be achievable only by an expression system that could produce rCVN with high efficiency and low cost.

\section{Expression rCVN in $E$. coli and other commensal bacteria}

Escherichia coli (E. coli) is the most widely used organisms for r-protein production because of its profound genetic and physiological characterization, its short generation time, the ease of handling, the established fermentation know-how and finally its high specific productivity. As a monomeric protein with 2 essential disulfide-bonds and no glycosylation, the initial heterologous expression of CVN was performed in the periplasmic space of E. coli. Boyd et al synthesized a sequence coding for the FLAG-CVN fusion, and succeeded in expressing it in $E$. coli. However, the product was a mixture of a series CVN derivatives, including intact protein, truncated protein and ompA fused proteins that decreased its anti-HIV potency and purity. Substitution of the ompA signal peptide with the pelB sequence resulted in intact rCVN, but this expression system yielded only $10 \mathrm{mg}$ target protein per liter of culture (Boyd et al. 1997). In addition, the purification process based on HPLC could not meet the requirement of activity determination and other large scale operations. The low yield of CVN from the periplasmic space is due to its special sequence and membrane structure, the low chaperone and foldase level and the high periplasmatic protease concentration in the host cell. The secretion systems of E. coli result in comparably low product yields, making them only suitable for compounds marketed in small quantities, like orphan drugs.

To increase the yield of CVN, inclusion body (IB) expression in the cytoplasm of E. coli was attempted (Colleluori et al. 2005). Following refolding by a conventional process and purification by ion exchange chromatography, about $40 \mathrm{mg} / \mathrm{L}$ of $\mathrm{rCVN}$ was produced in shaking flask culture, and $140 \mathrm{mg} / 40 \mathrm{~g}$ wet cell/L for fed batch high-cell-density culture. This is the highest yield of $\mathrm{rCVN}$ reported to date. Unfortunately, the final product is a mixture of full-length monomeric and dimeric $\mathrm{rCVN}$ native protein, and 1 or $4 \mathrm{~N}$-terminal residues deleted isomers. The heterogeneity of rCVN from IB exposes the weakness of this type of expression. Several vectors to express CVN directly in E. coli were also tried, but the low 
yield and IB formation were disappointing. Finally, we turned our attention to the chaperon fused expression system. Fortunately, this system with a hexahistidine and small ubiquitin-related modifier (SUMO) double-tagged CVN lead to a soluble fusion protein in the cytoplasm of E. coli at a level of $>30 \%$ of the total soluble protein (TSP). With this construct, intact and native rCVN can be rapidly purified in a soluble and biologically active form by 2 rounds of affinity chromatography with one round of SUMO protease digestion in between (Gao et al. 2009). In a $30 \mathrm{~L}$ bioreactor using conventional fed-batch culture (FBC), more than $100 \mathrm{mg} / \mathrm{L}$ native $\mathrm{rCVN}$ was afforded (unpublished data). An N-terminal extended CVN derivative was also constructed and expressed using the same strategy. This CVN derivative displayed higher activity on cell viability and in a cell-to-cell fusion assay, as well as lower cytotoxicity. Furthermore, the yield of this CVN derivative under the same FBC conditions was approximately $170 \pm 10 \mathrm{mg} / \mathrm{L}$ (unpublished data). The higher yield of this CVN derivative did not result from higher expression in the cytoplasm of E. coli, but is due to the extended sequence on the N-terminal of CVN acting as a bridge between the SUMO and CVN, and thus facilitates the digestion by SUMO protease. Overexpression of soluble SUMO-CVN in the cytoplasm of $E$. coli to obtain intact, homogeneous, and monomeric rCVN by simple downstream processes, makes this system promising for practical applications.

CVN was also expressed in commensal Streptococcus gordonii either as excreted protein or attached to the bacterial cell surface. As an excreted protein, it was able to bind HIV-1 and when it was bound to the bacterium, it was able to capture HIV-1 (Giomarelli et al. 2002). Other work has demonstrated the utility of Lactobacillus jensenii as agents of mucosal drug delivery to secrete CVN. This recombinant lactobacillus bacterium has been shown to produce high levels of structurally intact r-protein, exhibiting potent antiviral activity against laboratory and primary HIV-1 isolates. For example, the 50\% inhibitory concentration of this lactobacillus-derived CVN to CCR5-tropic $\mathrm{HIV}_{\mathrm{BaL}}$ is only $0.3 \mathrm{nM}$ (Liu et al. 2006). The development of a novel, live microbicide that employs a commensal bacteria to deliver CVN to the vaginal channel is another fascinating application of CVN (Ndesendo et al. 2008).

\section{In eukaryotic host}

Pichia pastoris (P. pastoris) is an alternative host that, like E. coli, can be grown cheaply and 
rapidly, possesses certain posttranslational modification pathways, is able to secrete more efficiently and permits the production of r-proteins without intense process development. Introduction of the coding sequence for CVNs into P. pastoris demonstrate the potential for expression of rCVN in a eukaryotic system. Unfortunately, it is difficult to obtain native rCVN with this system because of high-mannose N-glycosylation at position N30 and P51 mediated dimerization of the final product in the hinge region, both of which result in a loss of antiviral activity of rCVN (Mori et al. 2002). Furthermore, the yield in P. pastoris was only 10 $\mathrm{mg} / \mathrm{L}$, which is very low compared with cytoplasmic expression in E. coli.

A more feasible eukaryotic system to express $\mathrm{CVN}$ is a transgenic plant. The yield is approximately $130 \mu \mathrm{g} / \mathrm{g}$ from fresh leaves of the total plant, and $0.635 \pm 0.298 \mathrm{mg} / \mathrm{L}$ in a $24 \mathrm{~d}$-cultured rhizosecretion system. A bioactivity assay proved that the tobacco synthesized CVN is almost all in the monomeric form (Sexton et al. 2006). Under optimized conditions, the yield of the rhizosecretion culture of CVN is $3.2 \mathrm{mg} / \mathrm{L}$, or $766 \mu \mathrm{g} / \mathrm{g}$ root dry weight $/ 24 \mathrm{~h}$. This is the highest reported yield for rhizosecretion of a heterologous protein. None the less, for commercial viability, extensive optimization should still be undertaken to further increase the yield of rCVN in this transgenic system (Colgan et al. 2009; Drake et al. 2009). After the successful expression rCVN in a transgenic plant, a fusion protein of CVN and HIV-neutralizing mAb b12 was also produced in this transgenic plant. It was demonstrated that each moiety of the fusion protein retained its binding ability to gp120, and that this fusion protein exhibited increased anti-HIV potency compared to b12 or CVN alone (Sexton et al. 2009). Thus, production of rCVN from a transgenic plant may be a new approach for the microbicide manufacturing, although the undeveloped down-stream processes, potential post-translational modifications, and the higher cost and lower yield compared to that of $E$. coli make it non-viable now for meeting the emergency of the HIV epidemic.

In conclusion, CVN, a promising microbicide candidate with a special primary structure that is sensitive to disulphide bond formation and side-chain modification, has been expressed in $E$. coli, yeast and a transgenic plant (Table 1). The transgenic plant system is the most sophisticated, and represents the future of production of this drug candidate. At this moment though, the soluble expression in the cytoplasm of E. coli might be the only feasible option. 


\section{Antiviral activity and a pre-clinical study of CVN as a microbicide}

\section{Antiviral activities and drug targets of CVN}

CVN was initially isolated as part of a screening program searching for naturally occurring virucidal agents that could be developed into anti-HIV microbicides. It irreversibly inactivates a broad range of immunodeficiency viruses such as T-tropic, M-tropic and dual tropic primary clinical isolates of HIV, many T-tropic laboratory strains of HIV-1, HIV-2, simian immunodeficiency virus, and feline immunodeficiency virus (Boyd et al. 1997). As a potent virucidal protein, $\mathrm{CVN}$ is effective against most $\mathrm{HIV}$ strains with an $\mathrm{EC}_{50}$ of less than $1 \mathrm{nM}$ and a $\mathrm{CC}_{50}$ greater than $400 \mathrm{nM}$ (Table 2). The antiviral activity of $\mathrm{CVN}$ includes direct virucidal efficacy, inhibition of cell-to-cell fusion, virus-to-cell fusion and cell-to-cell transmission. Preventing of the fusion and transmission of HIV-1 between infected and uninfected cells might greatly contribute to the potency of CVN against HIV(Dey et al. 2000). The potent HIV-inactivation ability of CVN makes this protein of particular interest in the development of a microbicide that would be the first line of defense in preventing the sexual transmission of HIV. Since the entry inhibitor Enfuvirtide (T-20) has been approved by Food and Drug Administration, and been shown to constitute an important category of anti-HIV drugs, CVN, a potent fusion inhibitor, also might be developed into a therapeutic compound against HIV-1if its potential mitogenicity and immunogenicity were attenuated or eliminated by means of PEGlation or other modification (Zappe et al. 2008). Another interesting application of CVN is its potential use as a targeting agent. A fusion protein consisting of CVN and Pseudomonas exotoxin PE38 showed enhanced cytotoxicity to HIV-infected gp120-expressing H9 cells, raising the possibility that HIV infected cells could be targeted with these chimeric molecules (Mori et al. 1997).

The carbohydrate moiety of gp120 consists of 24 N-linked oligosaccharides, among which 11 are believed to be high-mannose or hybrid type, and 13 are complex type. CVN exerts its activity by binding to high-mannose oligosaccharides, located predominantly in the C2-C4 region of gp120, and prevents the virus entry by blocking fusion with the cell membrane and cell-to-cell transmission ( $\mathrm{Hu}$ et al. 2007; Shenoy et al. 2001). The 1.35 A high-resolution structure of P51G-m4-CVN suggests that the Arg-76 and Glu-41 residues of CVN are critical 
components for the high mannose specificity and affinity. Upon binding to gp120, Arg-76 undergoes a large conformational change, bringing its side chain from an unlocked position to a locked position, in which two direct hydrogen bonds to the ligand are formed. Glu-41 may contribute to the tight binding of the sugar and possibly in the selectivity for Man $\alpha(1-2)$ Man $\alpha$ (Fromme et al. 2008). Recently, molecular-dynamics simulations in solution demonstrated no conformational preferences for Arg-76. Instead, there is a very stable eight-hydrogen-bond network between the di-mannose ligand in gp120 and the predominant main-chain atoms in CVN (Vorontsov et al. 2009). Thus, the mutual interaction between CVN and gp120 might contribute simultaneously to their high affinity and specificity. This mechanism provides guidance for the microbicide development of $\mathrm{CVN}$, as well as for the design of CVN derivatives with enhanced antiviral activity.

In addition to immunodeficiency viruses, $\mathrm{CVN}$ is also effective against Ebola virus, influenza $\mathrm{A}$ and $\mathrm{B}$, hepatitis $\mathrm{C}$ virus, measles virus, herpes simplex virus type-1 (HSV-1) and HSV-6 (Balzarini 2007; Buffa et al. 2009; Helle et al. 2006; O'Keefe et al. 2003). The mutual feature of the viruses that are sensitive to $\mathrm{CVN}$ is that of N-linked high-mannose oligosaccharides on the surface glycoprotein, which constitute the unique binding sites for CVN (Barrientos et al. 2006). In a similar fashion to its effect on HIV, CVN not only blocks the entry of HSV-1 to target cells, but is also capable of significantly inhibiting membrane fusion mediated by HSV glycoproteins (Tiwari et al. 2009). The potent inhibitory activity of CVN against HSV-1 and other viruses suggests that this protein can be used not only for a topical microbicide against HIV-1, but also for the development of a broad-spectrum antiviral reagent for other enveloped viruses.

\section{Preclinical test of CVN against HIV}

In vivo studies with CVN formulated as a gel, have shown promising protection against male or female macaques (Macaca fascicularis) rectal or vaginal challenged with the highly pathogenic SHIV89.6P virus. Furthermore, CVN produced no cytotoxicity or clinical adverse effects in neither the in vitro nor in vivo model (Tsai et al. 2004; Tsai et al. 2003). Because the efficacy of a topical microbicides might be weakened by the dilution or neutralization of the vaginal fluid, semen, and personal sanitation habits, or interfered by the commensal bacteria, 
in vitro and ex vivo models of female genital tissue explants were established to evaluate these impacts (Buffa et al. 2009). It was demonstrated that the potent activity of CVN remained in low nanomolar range in the presence of whole semen and was minimally impacted by the presence of Candida albicans. Furthermore, CVN potently inhibited infection of ectocervical explants and virus dissemination by tissue-emigrating cells.

In another preclinical test, $\mathrm{CVN}$ and two other microbicide candidates currently in clinical trials, i.e., PRO 2000 and PMPA gel (tenofovir), were evaluated in a novel penile tissue explant model (Fischetti et al. 2009). It was found that CVN conferred 95\% protection against HIV-1 at $11 \mu \mathrm{g} / \mathrm{ml}$, which is similar to that seen in cervical explants and is a dose 1/500 of that shown to be protective in macaques. As a control, the dose for PRO2000 to confer total protection was 10 times greater than that of CVN, and for PMPA, the dose was almost 100 times higher. The ability to block HIV-1 transfer by migratory cells is in agreement with the ability of CVN to weaken dendritic cell specific HIV-1 transmission in vitro. CVN was not toxic for male or female genital tissue explants, but a degree of cytokine upregulation following $2 \mathrm{~h}$ exposure to CVN, was observed. Together, these studies suggest that CVN is a good candidate for further testing in non-human-primates followed by human clinical trials, although the potential mitogenic properties of CVN raise some concern about its safety.

\section{Comparison between CVN and other lectin-based candidates}

In addition to CVN, several lectins also exhibit significant activity against HIV and other enveloped viruses. So far, the most promising lectin-based anti-HIV candidates are CVN, scytovirin (SVN), Microcystis viridis lectin (MVL), and griffithsin (GRFT), all of which are found in algae. CVN and SVN take only nanomoles to inhibit half of the HIV virus in vitro and the inhibitory activity of GRFT is even stronger, with an EC50 2/5 of that of CVN. GRFT possesses no measurable lymphoprolifreation activity and is probably a safer candidate. However, the chemical and physical stability of GRFT is not as well as that of CVN and its antiviral effect and safety remain to be evaluated in transmission animal models. Different from most of other candidates, CVN binds strongly with glycoproteins having Man8 or Man9, regardless of the number of glycans on a glycoprotein, accounting for its strong antiviral activity. Actinohivin (AH), a lectin found in a cultured actinomyete, has showed more specific 
affinity to gp120 because, unlike CVN, it could not bind with a single High-mannose type glycan, and thus might be less toxic (Tanaka et al. 2009). Although CVN may cause side effects such as cytotoxicity and mitogenic activity, it has been proved effective and safe in vaginal and rectal transmission models. Large-scale production is another important issue in microbisides development and remains to be a challenge for lectins. Great advantages have been made in large-scale production of CVN with low cost, whereas efficient expression of GRFT has recently proved successful only in transgenic plant, with a yield of up to $300 \mathrm{mg} / \mathrm{Kg}$ leaf (O'Keefe et al. 2009). Continuous advances in research provide more choices for the development of lectin microbicides, and CVN owns its advantages to be a promising candidate.

\section{Conclusions and Perspectives}

Results from clinical trial on large-scale HIV prevention have been disappointing for the first generation of microbicide candidates, such as Buffergel, Carraguard, SAVVY, PRO2000 etc (Morris and Lacey. 2010). CVN is a promising microbicide candidate that was discovered 12 years ago and has been thoroughly tested in different assay and pharmacological models. It has displayed an impressive potential as a microbicides, and could even be a targeting reagent. Using the present technology, it may be possible to produce CVN on large scale and at low cost. The soluble cytoplasm expression of native rCVN, plus the established know-how of the bioprocesses of E. coli-produced biologics in the industrial sector, might provide a ready solution for the manufacture of this microbicide candidate. Other sophisticated approaches provide a backup for future manufacturing of the drug. Progress in structural mechanism investigation, pharmacological evaluation and heterologous production of $\mathrm{CVN}$, and the breakthrough in population studies of other microbicides confer a potential on CVN. In addition, the promising progress of a HIV vaccine (Cohen 2009) highlighted the possibility to build a combinational program including microbicides, vaccines, and/or pre-exposure prophylaxis, as well as behavioral science interventions for more effective HIV-1 prevention.

\section{Acknowledgements}

The authors are most grateful to Prof. A. Steinbüchel for supporting this review. Unpublished 
data referred to in this manuscript were partially supported by grants from the Ministry of Science and Technology of China (2008BAI63B05), the Program for New Century Excellent Talents in University (NCET-07-0376), and Grant-in-Aid from the Tokyo Biochemistry Research Foundation (TBRF-RF-08-52). 


\section{References}

Balzarini J (2007). Carbohydrate-binding agents: a potential future cornerstone for the chemotherapy of enveloped viruses? Antivir Chem Chemother 18:1-11

Balzarini J, Van Damme L (2007). Microbicide drug candidates to prevent HIV infection. Lancet 369:787-797

Barrientos LG, Louis JM, Botos I, Mori T, Han Z, O'Keefe BR, Boyd MR, Wlodawer A, Gronenborn AM (2002). The domain-swapped dimer of cyanovirin- $\mathrm{N}$ is in a metastable folded state: reconciliation of X-ray and NMR structures. Structure 10:673-686

Barrientos LG, Matei E, Lasala F, Delgado R, Gronenborn AM (2006). Dissecting carbohydrate-Cyanovirin-N binding by structure-guided mutagenesis: functional implications for viral entry inhibition. Protein Eng Des Sel 19:525-535

Bewley CA, Gustafson KR, Boyd MR, Covell DG, Bax A, Clore GM, Gronenborn AM (1998). Solution structure of cyanovirin-N, a potent HIV-inactivating protein. Nat Struct Biol 5:571-578

Botos I, O'Keefe BR, Shenoy SR, Cartner LK, Ratner DM, Seeberger PH, Boyd MR, Wlodawer A (2002). Structures of the complexes of a potent anti-HIV protein cyanovirin-N and high mannose oligosaccharides. J Biol Chem 277:34336-34342

Boyd MR, Gustafson KR, McMahon JB, Shoemaker RH, O'Keefe BR, Mori T, Gulakowski RJ, Wu L, Rivera MI, Laurencot CM, Currens MJ, Cardellina JH, 2nd, Buckheit RW, Jr., Nara PL, Pannell LK, Sowder RC, 2nd, Henderson LE (1997). Discovery of cyanovirin-N, a novel human immunodeficiency virus-inactivating protein that binds viral surface envelope glycoprotein gp120: potential applications to microbicide development. Antimicrob Agents Chemother 41:1521-1530

Buffa V, Stieh D, Mamhood N, Hu Q, Fletcher P, Shattock RJ (2009). Cyanovirin-N potently inhibits human immunodeficiency virus type 1 infection in cellular and cervical explant models. J Gen Virol $90: 234-243$

Cohen J (2009). HIV/AIDS research. Beyond Thailand: making sense of a qualified AIDS vaccine "success". Science 326:652-653

Colgan R, Atkinson CJ, Paul M, Hassan S, Drake PM, Sexton AL, Santa-Cruz S, James D, Hamp K, Gutteridge C, Ma JK (2009). Optimisation of contained Nicotiana tabacum cultivation for the production of recombinant protein pharmaceuticals. Transgenic Res [Epub ahead of print]

Colleluori DM, Tien D, Kang F, Pagliei T, Kuss R, McCormick T, Watson K, McFadden K, Chaiken I, Buckheit RW, Jr., Romano JW (2005). Expression, purification, and characterization of recombinant cyanovirin-N for vaginal anti-HIV microbicide development. Protein Expr Purif 39:229-236 
Dey B, Lerner DL, Lusso P, Boyd MR, Elder JH, Berger EA (2000). Multiple antiviral activities of cyanovirin-N: Blocking of human immunodeficiency virus type 1 gp120 interaction with CD4 and coreceptor and inhibition of diverse enveloped viruses. J Virol 74:4562-4569

Drake PM, Barbi T, Sexton A, McGowan E, Stadlmann J, Navarre C, Paul MJ, Ma JK (2009). Development of rhizosecretion as a production system for recombinant proteins from hydroponic cultivated tobacco. Faseb J 23: 3581-3589

Fischetti L, Barry SM, Hope TJ, Shattock RJ (2009). HIV-1 infection of human penile explant tissue and protection by candidate microbicides. Aids 23:319-328

Fromme R, Katiliene Z, Fromme P, Ghirlanda G (2008). Conformational gating of dimannose binding to the antiviral protein cyanovirin revealed from the crystal structure at 1.35 A resolution. Protein Sci 17:939-944

Gao X, Chen W, Guo C, Qian C, Liu G, Ge F, Huang Y, Kitazato K, Wang Y, Xiong S (2009). Soluble cytoplasmic expression, rapid purification, and characterization of cyanovirin-N as a His-SUMO fusion. Appl Microbiol Biotechnol [Epub ahead of print]

Giomarelli B, Provvedi R, Meacci F, Maggi T, Medaglini D, Pozzi G, Mori T, McMahon JB, Gardella R, Boyd MR (2002). The microbicide cyanovirin-N expressed on the surface of commensal bacterium Streptococcus gordonii captures HIV-1. Aids 16:1351-1356

Grant RM, Hamer D, Hope T, Johnston R, Lange J, Lederman MM, Lieberman J, Miller CJ, Moore JP, Mosier DE, Richman DD, Schooley RT, Springer MS, Veazey RS, Wainberg MA (2008). Whither or wither microbicides? Science 321:532-534

Gustafson KR, Sowder RC, 2nd, Henderson LE, Cardellina JH, 2nd, McMahon JB, Rajamani U, Pannell LK, Boyd MR (1997). Isolation, primary sequence determination, and disulfide bond structure of cyanovirin-N, an anti-HIV (human immunodeficiency virus) protein from the cyanobacterium Nostoc ellipsosporum. Biochem Biophys Res Commun 238:223-228

Helle F, Wychowski C, Vu-Dac N, Gustafson KR, Voisset C, Dubuisson J (2006). Cyanovirin-N inhibits hepatitis $\mathrm{C}$ virus entry by binding to envelope protein glycans. J Biol Chem 281:25177-25183

Hu Q, Mahmood N, Shattock RJ (2007). High-mannose-specific deglycosylation of HIV-1 gp120 induced by resistance to cyanovirin-N and the impact on antibody neutralization. Virology 368:145-154

Huskens D, Vermeire K, Profy AT, Schols D (2009). The candidate sulfonated microbicide, PRO 2000, has potential multiple mechanisms of action against HIV-1. Antiviral Res 84: 38-47

Liu X, Lagenaur LA, Simpson DA, Essenmacher KP, Frazier-Parker CL, Liu Y, Tsai D, Rao SS, Hamer DH, Parks TP, Lee PP, Xu Q (2006). Engineered vaginal lactobacillus strain for mucosal delivery of the human immunodeficiency virus inhibitor cyanovirin-N. Antimicrob Agents Chemother 
$50: 3250-3259$

Liu Y, Carroll JR, Holt LA, McMahon J, Giomarelli B, Ghirlanda G (2009). Multivalent interactions with gp120 are required for the anti-HIV activity of Cyanovirin. Biopolymers 92:194-200

Mori T, Barrientos LG, Han Z, Gronenborn AM, Turpin JA, Boyd MR (2002). Functional homologs of cyanovirin- $\mathrm{N}$ amenable to mass production in prokaryotic and eukaryotic hosts. Protein Expr Purif $26: 42-49$

Mori T, Gustafson KR, Pannell LK, Shoemaker RH, Wu L, McMahon JB, Boyd MR (1998). Recombinant production of cyanovirin-N, a potent human immunodeficiency virus-inactivating protein derived from a cultured cyanobacterium. Protein Expr Purif 12:151-158

Mori T, Shoemaker RH, McMahon JB, Gulakowski RJ, Gustafson KR, Boyd MR (1997). Construction and enhanced cytotoxicity of a [cyanovirin-N]-[Pseudomonas exotoxin] conjugate against human immunodeficiency virus-infected cells. Biochem Biophys Res Commun 239:884-888

Morris GC, Lacey CJ (2010). Microbicides and HIV prevention: lessons from the past, looking to the future. Curr Opin Infect Dis 23:57-63

Ndesendo VM, Pillay V, Choonara YE, Buchmann E, Bayever DN, Meyer LC (2008). A review of current intravaginal drug delivery approaches employed for the prophylaxis of HIV/AIDS and prevention of sexually transmitted infections. AAPS PharmSciTech 9:505-520

O'Keefe BR, Smee DF, Turpin JA, Saucedo CJ, Gustafson KR, Mori T, Blakeslee D, Buckheit R, Boyd MR (2003). Potent anti-influenza activity of cyanovirin-N and interactions with viral hemagglutinin. Antimicrob Agents Chemother 47:2518-2525

O'Keefe BR, Vojdani F, Buffa V, Shattock RJ, Montefiori DC, Bakke J, Mirsalis J, d'Andrea AL, Hume SD, Bratcher B, Saucedo CJ, McMahon JB, Pogue GP, Palmer KE (2009). Scaleable manufacture of HIV-1 entry inhibitor griffithsin and validation of its safety and efficacy as a topical microbicide component. Proc Natl Acad Sci U S A 106:6099-6104

Sexton A, Drake PM, Mahmood N, Harman SJ, Shattock RJ, Ma JK (2006). Transgenic plant production of Cyanovirin-N, an HIV microbicide. Faseb J 20:356-358

Sexton A, Harman S, Shattock RJ, Ma JK (2009). Design, expression, and characterization of a multivalent, combination HIV microbicide. Faseb J 23: 3590-600

Shattock R, Solomon S (2004). Microbicides--aids to safer sex. Lancet 363:1002-1003

Shattock RJ, Moore JP (2003). Inhibiting sexual transmission of HIV-1 infection. Nat Rev Microbiol $1: 25-34$

Shenoy SR, O'Keefe BR, Bolmstedt AJ, Cartner LK, Boyd MR (2001). Selective interactions of the human 
immunodeficiency virus-inactivating protein cyanovirin-N with high-mannose oligosaccharides on gp120 and other glycoproteins. J Pharmacol Exp Ther 297:704-710

Tanaka H, Chiba H, Inokoshi J, Kuno A, Sugai T, Takahashi A, Ito Y, Tsunoda M, Suzuki K, Takenaka A, Sekiguchi T, Umeyama H, Hirabayashi J, Omura S (2009). Mechanism by which the lectin actinohivin blocks HIV infection of target cells. Proc Natl Acad Sci U S A 106:15633-15638

Terpe K (2006). Overview of bacterial expression systems for heterologous protein production: from molecular and biochemical fundamentals to commercial systems. Appl Microbiol Biotechnol $72: 211-222$

Tiwari V, Shukla SY, Shukla D (2009). A sugar binding protein cyanovirin-N blocks herpes simplex virus type-1 entry and cell fusion. Antiviral Res 84:67-75

Tsai CC, Emau P, Jiang Y, Agy MB, Shattock RJ, Schmidt A, Morton WR, Gustafson KR, Boyd MR (2004). Cyanovirin-N inhibits AIDS virus infections in vaginal transmission models. AIDS Res Hum Retroviruses 20:11-18

Tsai CC, Emau P, Jiang Y, Tian B, Morton WR, Gustafson KR, Boyd MR (2003). Cyanovirin-N gel as a topical microbicide prevents rectal transmission of SHIV89.6P in macaques. AIDS Res Hum Retroviruses 19:535-541

UNAIDS (2008). Report on the global AIDS epidemic 2008. In: Unaids.org. http://www.unaids.org/en/KnowledgeCentre/HIVData/GlobalReport/2008/2008_Global_report.asp. Accessed 6 Nov 2008

Vorontsov, II, Miyashita O (2009). Solution and crystal molecular dynamics simulation study of m4-cyanovirin-N mutants complexed with di-mannose. Biophys J 97:2532-2540

Yang F, Bewley CA, Louis JM, Gustafson KR, Boyd MR, Gronenborn AM, Clore GM, Wlodawer A (1999). Crystal structure of cyanovirin-N, a potent HIV-inactivating protein, shows unexpected domain swapping. J Mol Biol 288:403-412

Zappe H, Snell ME, Bossard MJ (2008). PEGylation of cyanovirin-N, an entry inhibitor of HIV. Adv Drug Deliv Rev 60:79-87 
Table 1 Compilation of the key features of recombinant CVN from various expression systems

\begin{tabular}{|c|c|c|c|}
\hline $\begin{array}{l}\text { Expression } \\
\text { type }\end{array}$ & Purification process and yield & Key features & References \\
\hline \multicolumn{4}{|c|}{ Blue alga Nostoc ellipsosporum } \\
\hline $\begin{array}{l}\text { Natural } \\
\text { product }\end{array}$ & $\begin{array}{l}\text { Solvent extraction and } \\
\text { precipitation, RP-HPLC. Yield } \\
\text { not determined. }\end{array}$ & Natural product, low yield. & $\begin{array}{l}\text { (Gustafson } \\
\text { et al. 1997) }\end{array}$ \\
\hline \multicolumn{4}{|l|}{ E. coli } \\
\hline $\begin{array}{l}\text { Periplasmic } \\
\text { expression }\end{array}$ & $\begin{array}{l}\text { Anti-Flag AC, RP-VLC and } \\
\text { RP-HPLC. Yield }<10 \mathrm{mg} / \mathrm{L}\end{array}$ & $\begin{array}{l}\text { Soluble expression of Flag fused and native } \\
\text { rCVN. Flag fusion decreased its activity, while } \\
\text { native rCVN was a mixture of intact and } \\
\text { truncated forms of CVN. }\end{array}$ & $\begin{array}{l}\text { (Boyd et al. } \\
\text { 1997) }\end{array}$ \\
\hline $\begin{array}{l}\text { Periplasmic } \\
\text { expression }\end{array}$ & $\begin{array}{l}\text { RP-VLC, RP-HPLC. Yield } \\
\text { approximately } 10 \mathrm{mg} / \mathrm{L}\end{array}$ & $\begin{array}{l}\text { Soluble expression of homogeneous full-length } \\
\text { rCVN under the lead of the pelB signal. }\end{array}$ & $\begin{array}{l}\text { (Mori et al. } \\
\text { 1998) }\end{array}$ \\
\hline $\begin{array}{l}\text { Periplasmic } \\
\text { expression }\end{array}$ & $\begin{array}{l}\text { Ni-NTA AC, RP-HPLC. Yield } \\
10 \mathrm{mg} / \mathrm{L} \text { (optimal conditions). }\end{array}$ & $\begin{array}{l}\text { Homogeneous C-terminal pentahistidine fused } \\
\text { rCVN and its Asn } 30 \text { and/or Pro51 substituted } \\
\text { mutants. }\end{array}$ & $\begin{array}{l}\text { (Mori et al. } \\
\text { 2002) }\end{array}$ \\
\hline $\begin{array}{l}\text { Cytoplasmic } \\
\text { IB expression }\end{array}$ & $\begin{array}{l}\text { Inclusion body refolding, IEC. } \\
\text { Yield } 40 \mathrm{mg} / \mathrm{L} \text { for flask } \\
\text { shaking. } 140 \mathrm{mg} / 40 \mathrm{~g} \text { wet cell/L } \\
\text { culture for FB-HCDC. }\end{array}$ & $\begin{array}{l}\text { High yield. Inclusion body. Heterologous final } \\
\text { product of monomeric and dimeric rCVN of } \\
\text { full-length native protein, and } 1 \text { or } 4 \\
\text { N-terminal residues deleted isomers. }\end{array}$ & $\begin{array}{l}\text { (Colleluori } \\
\text { et al. 2005) }\end{array}$ \\
\hline $\begin{array}{l}\text { Cytoplasmic } \\
\text { soluble } \\
\text { expression }\end{array}$ & $\begin{array}{l}\text { Ni-NTA AC, SUMO protease } \\
\text { cleavage. Yield } 3-4 \mathrm{mg} / \mathrm{g} \text { wet } \\
\text { cell, } 30 \% \text { of the TSP. }\end{array}$ & $\begin{array}{l}\text { Soluble expression in the cytoplasm of } E \text {. coli. } \\
\text { Simplified purification process and high yield. } \\
\text { Obtained intact and homogeneous native rCVN } \\
\text { from the His-SUMO-CVN fusion. }\end{array}$ & $\begin{array}{l}\text { (Gao et al. } \\
\text { 2009) }\end{array}$ \\
\hline \multicolumn{4}{|l|}{ Pichia pastoris } \\
\hline $\begin{array}{l}\text { Secreted } \\
\text { expression }\end{array}$ & $\begin{array}{l}\text { Ni-NTA AC. Yield } 10 \mathrm{mg} / \mathrm{L} \\
\text { (un-optimized condition) }\end{array}$ & $\begin{array}{l}\text { Ex-secreted expression of C-terminal } \\
\text { pentahistidine fused CVN. N-glycosylated into } \\
\text { an inactive form and conformational } \\
\text { heterogeneity for WT rCVN, but CVN P51G } \\
\text { mutant exhibited comparable activity and } \\
\text { stability. }\end{array}$ & $\begin{array}{l}\text { (Mori et al. } \\
\text { 2002) }\end{array}$ \\
\hline \multicolumn{4}{|c|}{ Nicotine abacus } \\
\hline $\begin{array}{l}\text { Transgenic } \\
\text { tobacco } \\
\text { expression }\end{array}$ & $\begin{array}{l}\text { Only detected by WB analysis. } \\
\text { Yield in plant: } 130 \mathrm{ng} / \mathrm{mg} \text { from } \\
\text { the fresh leaf, } 0.85 \% \text { of TSP. } \\
\text { yield for rhizosecretion: } \\
0.635 \pm 0.298 \mu \mathrm{g} / \mathrm{mL} \text { after } 24 \\
\text { days culture }\end{array}$ & $\begin{array}{l}\text { Soluble expression, the yield is higher than } \\
\text { reported IgGs in transgenic tobacco. Almost } \\
\text { monomeric form. Tobacco contains a high } \\
\text { content of toxic alkaloids. Restricted by } \\
\text { downstream process and NDA regulation for } \\
\text { the transgenic plant produced rCVN. }\end{array}$ & $\begin{array}{l}\text { (Sexton et } \\
\text { al. 2006) }\end{array}$ \\
\hline
\end{tabular}

RP-HPLC, reverse phase - high performance liquid chromatography; VLC, vacuum liquid chromatography;

AC, affinity chromatography; IEC, ion exchange chromatography; FB, fed-batch; HCDC, high cell density culture; SUMO: small ubiquitin-related modifier; WB, western blot 
Table 2 Antiviral activity of CVN against primary and laboratory HIV strains in cellular assay. Data were extracted from the data base of National Institute of Allergy and Infectious Diseases (NIAID) (http://www3.niaid.nih.gov/), accessed on the $17^{\text {th }}$ November 2009 from the webpage of http://chemdb.niaid.nih.gov/struct_search/misc/invitro.asp?aids=045707.

\begin{tabular}{|c|c|c|c|c|c|c|c|c|c|}
\hline HIV strain type & Cell type & $\begin{array}{l}\mathbf{E C}_{50} \\
(\mu \mathrm{M})\end{array}$ & $\begin{array}{l}\mathbf{C C}_{50} \\
(\mu \mathrm{M}) \\
\end{array}$ & TI & HIV strain type & Cell type & $\begin{array}{l}\mathbf{E C}_{50} \\
(\mu \mathrm{M}) \\
\end{array}$ & $\begin{array}{l}\mathbf{C C}_{50} \\
(\mu \mathrm{M}) \\
\end{array}$ & TI \\
\hline HIV-1(RF) & CEM-SS & 0.0001 & $>0.4$ & $>4000$ & HIV-1(VIHU) & PBL & 0.0055 & $>0.4$ & $>72.73$ \\
\hline HIV-1(RF) & U-937 & 0.0005 & $>0.4$ & $>800$ & HIV-2(ROD) & CEM-SS & 0.0076 & $>0.4$ & $>52.63$ \\
\hline HIV-1(IIIB) & CEM-SS & 0.00016 & $>0.4$ & $>2500$ & HIV-1(G910-6) & MT-2 & 0.0058 & $>0.4$ & $>68.97$ \\
\hline HIV-1(IIIB) & MT-2 & 0.0004 & $>0.4$ & $>1000$ & HIV-1(WEJO) & PBL & 0.0067 & $>0.4$ & $>59.7$ \\
\hline HIV-1(IIIB) & CEM-SS & 0.0004 & $>0.4$ & $>1000$ & HIV-1(89.6) & PBL & 0.0073 & $>0.4$ & $>54.79$ \\
\hline HIV-1(214) & CEM-SS & 0.0004 & $>0.4$ & $>1000$ & HIV-1(SLKA) & $\begin{array}{c}\text { Primary } \\
\text { macrophages }\end{array}$ & 0.0055 & $>0.4$ & $>72.73$ \\
\hline HIV-1(A17) & MT-2 & 0.0008 & $>0.4$ & $>500$ & HIV-1(Ba-L) & $\begin{array}{c}\text { Primary } \\
\text { macrophages }\end{array}$ & 0.017 & $>0.4$ & $>23.53$ \\
\hline HIV-1(205) & CEM-SS & 0.0008 & $>0.4$ & $>500$ & HIV-1(89.6) & $\begin{array}{c}\text { Primary } \\
\text { macrophages }\end{array}$ & 0.0368 & $>0.4$ & $>10.87$ \\
\hline HIV-1(G1) & CEM-SS & 0.0009 & $>0.4$ & $>444.44$ & HIV-1(Ada-M) & $\begin{array}{c}\text { Primary } \\
\text { macrophages }\end{array}$ & 0.0017 & $>0.4$ & $>235.29$ \\
\hline HIV-1(BAKI) & PBL & 0.0015 & $>0.4$ & $>266.67$ & HIV-1(RF) & CEM-SS & 0.00156 & 0.23 & 147 \\
\hline HIV-1(SK1) & CEM-SS & 0.0048 & $>0.4$ & $>83.33$ & HIV-1(NL4-3) & $\begin{array}{c}\text { U87(CD4+, } \\
\text { CCR5+) }\end{array}$ & 0.0253 & $\sim 1$ & $\sim 39.5$ \\
\hline HIV-1(MN) & MT-2 & 0.0023 & $>0.4$ & $>173.91$ & HIV-1(NL4-3) & $\begin{array}{c}\text { U87(CD4+, } \\
\text { CXCR4+) }\end{array}$ & 0.0035 & $<1$ & $<285$ \\
\hline HIV-2(MS) & CEM-SS & 0.0023 & $>0.4$ & $>173.91$ & HIV-1(NL4-3) & $\begin{array}{c}\mathrm{U} 87(\mathrm{CD} 4+ \\
\mathrm{CCR} 5+)\end{array}$ & 0.0253 & $>1$ & $>39.5$ \\
\hline HIV-1(WOME) & PBL & 0.0043 & $>0.4$ & $>93.02$ & & & & & \\
\hline
\end{tabular}

$\mathrm{EC}_{50}, 50 \%$ effective concentration. $\mathrm{CC}_{50}, 50 \%$ cytotoxic concentration. $\mathrm{TI}$, treatment index 
Fig. 1 Crystal structures of CVN. (A) The domain-swapped dimer of CVN. CVN is a three-dimensional domain-swapped dimer in the crystal structures with two primary sites near the hinge region and two secondary sites on opposite ends of the dimer. The Figure was extracted from PDB (http://www.rcsb.org/pdb/explore/explore.do?structureId=1L5E). (B) The crystal structure of rCVN complexed to a synthetic hexamannoside at 2.4-A resolution. The binding interface constitutes two stacked $\alpha(1-2)$-linked mannose rings for hexamannoside with the rest of the saccharide molecules pointing towards the solution. The Figure was extracted from PDB (http://www.rcsb.org/pdb/explore/explore.do?structureId=3GXY).

A

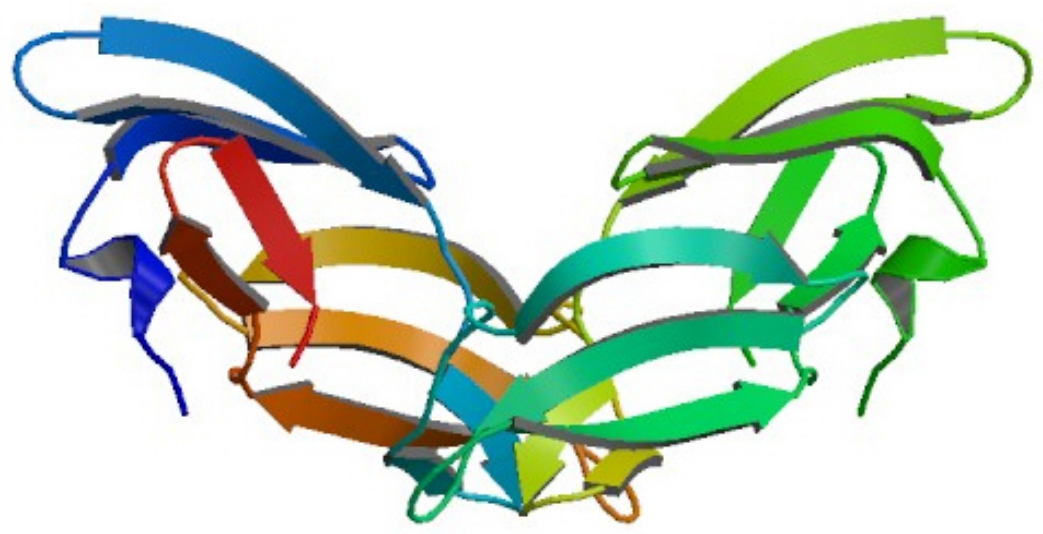

$\mathrm{B}$

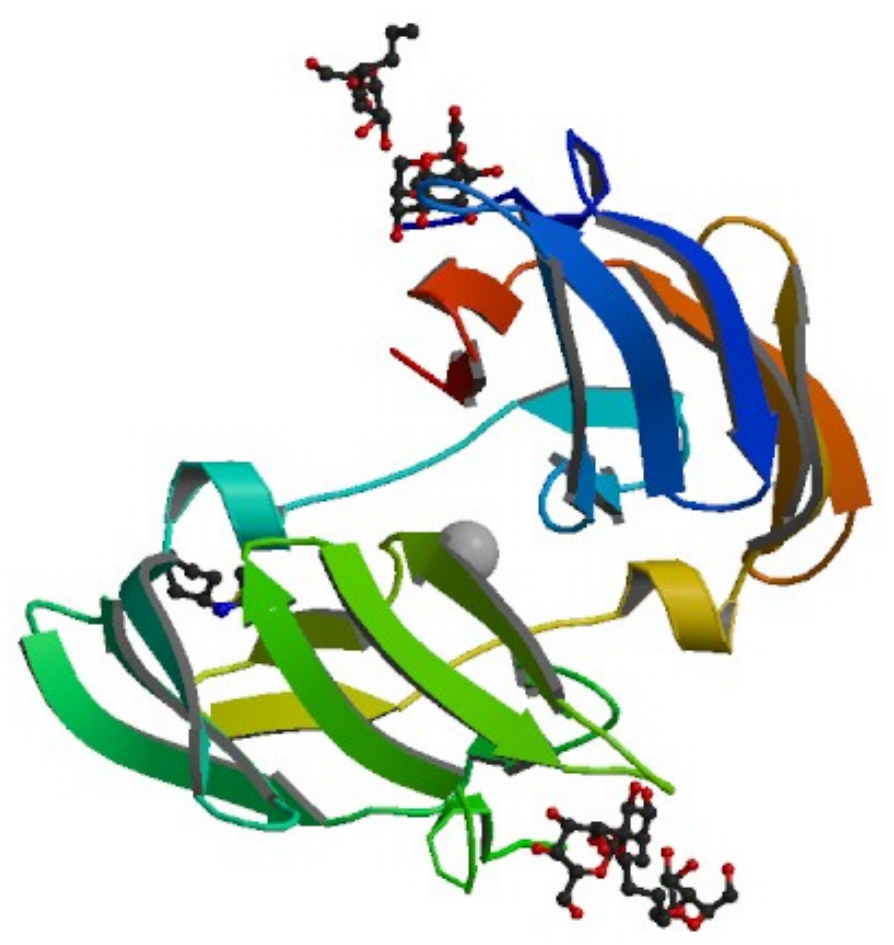

